\title{
Geomineralogical, Physiochemical, Thermal and Kinetic Characterisation of Selected Coals From the Benue Trough and Anambra Basins in Nigeria
}

Bemgba B. Nyakuma ( $\sim$ bnbevan2@live.utm.my )

Universiti Teknologi Malaysia https://orcid.org/0000-0001-5388-7950

Aliyu Jauro

Abubakar Tafawa Balewa University

Segun A. Akinyemi

Ekiti State University

Syie L. Wong

Rey Juan Carlos University: Universidad Rey Juan Carlos

Olagoke Oladokun

Covenant University

Tuan Amran T. Abdullah

Universiti Teknologi Malaysia

Research

Keywords: Geomineralogy, Thermokinetics, Coal, Benue Trough, Anambra Basin, Nigeria.

Posted Date: December 16th, 2020

DOI: https://doi.org/10.21203/rs.3.rs-127364/v1

License: (1) This work is licensed under a Creative Commons Attribution 4.0 International License.

Read Full License 


\title{
Geomineralogical, Physiochemical, Thermal and Kinetic Characterisation of Selected Coals from the Benue Trough and Anambra Basins in Nigeria
}

\author{
Bemgba B. Nyakuma ${ }^{*}$, Aliyu Jauro ${ }^{2}$, Segun A. Akinyemi ${ }^{3}$, Syie L. Wong ${ }^{4}$, \\ Olagoke Oladokun ${ }^{5}$, Tuan Amran T. Abdullah ${ }^{1 *}$ \\ ${ }^{1}$ School of Chemical and Energy Engineering, Faculty of Engineering, \\ Universiti Teknologi Malaysia, Skudai, Johor, Malaysia. \\ 2 National Centre for Petroleum Research and Development, Abubakar \\ Tafawa Balewa University, Bauchi State, Nigeria. \\ ${ }^{3}$ Department of Geology, Faculty of Science, Ekiti State University, \\ Ado Ekiti, Ekiti State, Nigeria. \\ ${ }^{4}$ Dpto. Matemática Aplicada, Ciencia Ingeniería Materiales Tecnología \\ Electronica, Universidad Rey Juan Carlos, Madrid, Spain. \\ 5 Department of Chemical Engineering, Covenant University, \\ Canaan Land, Ota, Ogun State, Nigeria.
}

*Corresponding Author Email: bbnyax1@gmail.com, tuanamran@utm.my

\begin{abstract}
This study examined the geomineralogical, physiochemical, thermal, and kinetic characteristics of selected coals from Chikila (CHK), Lafia Obi (LFB) and Okaba (OKB) in the Benue Trough and Anambra Basins of Nigeria. Physicochemical characterisation revealed significant quantities of carbon, volatiles, fixed carbon, and heating values (25-30 MJ/kg) but low moisture, and ash contents. The fuel properties indicate subbituminous to bituminous rank coals. The morphological, microstructure and elemental analyses revealed heterogeneous sized coal particles with a glassy sheen due to clay and aluminosilicate minerals such as quartz, alumina, kaolinite, and hematite. Based on thermal analysis, the coal samples are highly reactive and experienced significant thermal degradation as evident in the high mass losses $\left(M_{L}\right.$ $=91.59-94.04 \%)$ and low residual masses $\left(R_{M}=5.96 \%-8.41 \%\right)$, which are observed in the orders $\mathrm{LFB}>\mathrm{OKB}>\mathrm{CHK}$ for $M_{L}$ and $\mathrm{CHK}>\mathrm{OKB}>\mathrm{LFB}$ for $R_{M}$. LFB experienced the highest $M_{L}$ and lowest $R_{M}$ indicating it is more thermally reactive compared to OKB and CHK. Kinetic analysis by Coats-Redfern model revealed low values of activation energy, $E_{a}$ (30.07 - 43.91) $\mathrm{kJ} / \mathrm{mol}$ and frequency factor $A\left(1.16 \times 10^{-02}-6.73 \times 10^{-02}\right) \mathrm{min}^{-1}$ deduced at high $\mathrm{R}^{2}$ (0.98-0.99). The kinetic parameters demonstrated that the selected coal samples are highly reactive under oxidative conditions which are suited for energy recovery through pulverised coal combustion.
\end{abstract}

Keywords: Geomineralogy, Thermokinetics, Coal, Benue Trough, Anambra Basin, Nigeria. 


\section{Introduction}

Coal is a highly carbonaceous, brown-to-black coloured, organic sedimentary rock formed from the high temperature and pressure reactions on tectonically buried plant materials in the earth's crust (Speight 2013; Gräbner 2014). Historically, the formation of coal began between 290 million and 360 million years ago arising from the physicochemical changes which transformed vegetation into peat and eventually into the various ranks of coal. It is also considered a solid fossil fuel formed from the remnants of antediluvian plant life collected in peat bogs or coal forming swamps (Speight 2012; World Coal Association 2017). Over the years, coal has become an integral part of the global energy mix due to its wide distribution and abundance worldwide. Due to its prevalence and wide accessibility, coal accounts for $64 \%$ of globally economically recoverable fossil fuels (or one trillion tonnes) when compared to oil (19\%) and natural gas (IEA 2012). The most significant deposits located in the United States, Russia, Australia, China, India, Indonesia, Germany, Poland and Ukraine collectively account for $\sim 90 \%$ of the total global reserves (Mining Technology 2020). However, energy data indicates that the commercial mining of coal, projected at 6.9 billion tonnes, occurs in over 50 countries worldwide for various applications (World Coal Association 2017).

Globally, coal is utilised as feedstock for the production of iron, steel, cement as well as chemicals, fuels, and fertilisers (Miller 2016). The primary utilisation of coal is for the electric power generation, where it accounts for $\sim 40 \%$ or about 8200 terawatt-hours (TWh) annually of the global energy mix (IEA 2020). Coal-fired power generation provides cheap and reliable electricity required to provide the heat and power needs of domestic and industrial locations (IEA-OECD 2002; IEA 2020). Hence, coal utilisation in developing countries is crucial to socio-economic growth, infrastructural development, and poverty alleviation (IEACCC 2020). According to the IEA, coal-fired power generation has the potential to also address energy poverty (IEA 2020), which currently afflicts over 1.3 to 3.5 billion people or $50 \%$ of humanity who have either zero or limited access to electricity (Nerini et al. 2016; Adewuyi et al. 2019). The lack of electricity and associated energy crises is prevalent in Africa's largest economy and most populous nation, Nigeria. Over the years, the country has experienced persistent low voltage, load shedding, intermittent power outages and extended blackouts (Emodi 2016; Adewuyi et al. 2019). These challenges are ascribed to poor power generation and distribution along with dilapidated power infrastructure which has resulted in transmission losses and system failures in the national electricity grid (Oseni 2011; Sambo et al. 2012; Emodi and Yusuf 2015; Emovon et al. 2018). According to analysts advocate for the diversification of the national energy mix currently dominated by hydropower and gas-fired 
electricity could address the current issues associated with power generation in Nigeria (Musa 2010; Aliyu et al. 2013; Mohammed et al. 2013; Oyedepo 2014).

One potential solution is the adoption of coal-fired electricity based on the vast coal reserves in Nigeria (Sambo 2009; Ohimain 2014; Oboirien et al. 2018). The nation's reserves of coal are estimated at 640 million proven and 2.75 billion tonnes of provisional tonnes, which are located across the six geopolitical regions of Nigeria (Obaje 2009; Chukwu et al. 2016). Despite the vast reserves, wide accessibility, and availability, the utilization of coal for electricity generation is non-existent in Nigeria. One of the widely reported reasons for zero coal utilisation is the lack of comprehensive data on the fuel and energetic properties of the various coal deposits in the country. The limited technical expertise and scientific knowledge along with the three E's energy, economic, and environmental ramifications of coal utilisation also need to be addressed in detail. Therefore, this paper seeks to examine the physicochemical, geomineralogical, thermal, and kinetic fuel properties of selected coals from Chikila (CHK), Lafia Obi (LFB) and Okaba (OKB) in the Benue Trough and Anambra Basins of Nigeria.

\section{Geological Settings}

The Benue Trough (BT) is an interior, rift, and sedimentary basin comprising a regional structure spanning $150 \mathrm{~km}$ in width with origins dating back to the Late Mesozoic and Early Cenozoic when the African and South American continents were separated (Olade 1975; Petters 1982). The region comprises $6 \mathrm{~km}$ thick sediments dating back to the CretaceousTertiary era, although selected parts pre-existed in the middle Santonian, which have been subjected to compression, deformation and upliftment (Benkhelil 1989). The petrographic and geochemical analyses indicate the Benue Trough is characterised by an inactive margin tectonic environment. Structurally, the Benue trough is partitioned into three (3) subbasins based on the stratigraphic arrangement and transformations in the physiographic and lithostratigraphic taxonomy (Ehinola et al. 2002). The Lafia Obi (LFB) coal deposit is located in the middle Benue Trough (MBT), whereas the Chikila (CHK) coal deposits are situated in the Upper Benue Trough (UBT). The MBT consists of the Precambrian Basement superimposed unconformably by the Awe, Arufu, and Uomba formations that comprise the Asu River Group (Offodile 1980). The Lafia Formation unconformably overlies the Agwu Formation, which is considered a Late Turonian or Early Santonian coal-bearing Formation (Offodile 1976). However, The UBT is initiated mainly by the N-S trending Gongola arm and the E-W trending Yola arm separated by the axial zone of the trough, which comprises four major NE-SW faults 
namely Bima-Teli, Kaltungo, Gombe, and Burashika (Benkhelil 1989; Zaborski et al. 1997). The Anambra Basin, which covers about $2200 \mathrm{~km}^{2}$, is geographically situated at the borderline intersection between the Bida and Niger Delta Basins of southern Nigeria (Odunze et al. 2013; Nwajide and Reijers 1996). The basin is bordered by the Niger Delta to the South, the Niger valley to the North West, and Jos chain to the North and Lafia to the North East (Odunze et al. 2013). Historically, the Anambra Basin originates from the Abakaliki-Benue Basin through Santonian tectonic events during which the N-S compression of the European and African plates creased the Abakaliki Anticlinorium (Burke 1996; Maluski et al. 1995; Hoque and Nwajide 1984). The basin's stratigraphic evaluation indicates it comprises CampanianPaleocene based sediments estimated at $2500 \mathrm{~m}$ (Odunze et al. 2013), which are deposited in the Ajali, Bende, Imo, Mamu, Nsukka, and Nkporo formations (Nwajide and Reijers 1996).

\section{Experimental}

\subsection{Materials and Sampling}

The sample materials examined in this study were selected from coalmines or seams located in the Benue Trough and Anambra Basin of Nigeria. The dark brown to black rock coal samples, namely; Chikila (CHK), Lafia Obi (LFB), and Okaba (OKB) were acquired by direct excavation from coal bed mines distributed across various locations in each seam to guarantee representative channel samples. The $\mathrm{CHK}$ coal was acquired from Chikila village located on the outskirts of Guyuk town in Guyuk local government area of Adamawa state located in the Upper Benue Trough of Nigeria. The LFB coal sample was acquired from deposits in LafiaObi local government area of Nasarawa state, which is situated in the Middle Benue Trough of Nigeria. The OKB coal was acquired from the Okaba mine located northeast of Ankpa local government area in Kogi State and located in the Anambra Basin. The rock sized coal samples were then ground in a dry mill grinder (Model: Panasonic Mixer MX-AC400, Malaysia) before sifting with an analytical sieve of Mesh size 60 (Brand: Retsch ${ }^{\mathrm{TM}}$, Germany) to acquire coal particles below $250 \mu \mathrm{m}$ for further characterisation.

\subsection{Methods}

\subsubsection{Chemical Fuel Analyses}

The chemical analysis of the coal samples was examined by ultimate, proximate, and calorific analyses. The ultimate analysis was carried out to determine the composition of 
carbon, hydrogen, nitrogen, and sulphur using an elemental analyser (Model: vario MACRO Cube, Germany). The oxygen content was computed by difference from the sum of the other empirically determined elements. The proximate analysis was performed through thermogravimetric analysis (TGA) (Model: Shimadzu TG-50, Japan) to determine the composition of moisture, volatile matter, and ash based on the procedure reported in the literature (Donahue and Rais 2009). The fixed carbon was subsequently calculated by difference from the sum of the other empirically determined contents. The calorific analysis of the coal samples was performed by bomb calorimetry (Model: IKA C2000, USA) according to the ASTM standard D-2015 to determine the higher heating value (HHV).

\subsubsection{Morphological and Microstructural Analyses}

The morphologic and microstructure properties of the coal samples were determined by scanning electron microscopy (SEM) and energy dispersive X-ray (EDX) spectroscopy. In this study, the SEM analysis was carried out using the analyser (Model: JEOL JSM IT 300 LV, Germany) based on the operating conditions; voltage $20 \mathrm{kV}$ and a working distance of $5 \mathrm{~mm}$. For each test, each powdered coal sample was spray deposited on the carbon epoxy tape preplaced on grain mounts before analysis. Next, the samples were sputter-coated with gold using the thin film automatic sputter coater (Model: Quorum Q150R S, USA) fitted with $57 \mathrm{~mm}$ diameter disc-style targets and operating at the pressure of $2 \times 10^{-03} \mathrm{mbar}$. The samples were sputter-coated to avert the impacts of charging, damage to the electron beam, and increase the clarity of image during the analysis. On completion, the grain mounts containing the samples were transferred to the SEM analysis for morphology and microstructure analysis. The SEM micrographs were subsequently captured at a magnification of $\times 2000$.

\subsubsection{Micro-Elemental Analyses}

The EDX analysis was performed on the analyser (Model: JEOL JSM IT 300 LV, Germany) based on the point ID technique, which detects the elements present in the mapped zones of the SEM micrographs. The average composition of each element (weight per cent, wt.\%) was determined by charge balance and computed through the point ID analysis feature of the EDX software (AZTEC, Oxford Instruments, England).

\subsubsection{Mineralogical Analysis}

The mineral composition of the coal samples was examined by wavelength dispersive X-ray fluorescence (WDXRF) spectroscopy. The tests were performed with the WDXRF 
analyser (Model: Rigaku, ZXS Primus II WDXRF, Japan) that employs rhodium (Rh) target end-window based X-ray tubes. The device is equipped with a smart sample loading system and the proprietary mapping feature for determining the topography and distribution of sample elements. Based on the pellet method, each coal sample was weighed, pelletized, and transferred to the sample holder of the WDXRF. The sample preparation process was done to ensure the sensitivity of the calibration and reliability of the measurements. Next, the sample test was initiated and the run time lasted approximately one minute after which, the composition of metal and non-metallic present in the coal samples was measured with the WDXRF analyser. The oxides of each metal and non-metallic element for each coal sample were subsequently computed (after automatic corrections) using the software Rigaku XRF analysis (Version: Rigaku EZ-scan, Japan) combined with the SQX fundamental parameters.

\subsubsection{Thermochemical Analysis}

The thermochemical properties of the coal samples were examined by thermogravimetric analysis (TGA) based on the non-isothermal heating program of the TG Analyser (Model: Shimadzu TG-50, Japan). During the TG runs, $13 \mathrm{mg}$ of each coal sample was weighed and transferred to an alumina crucible $(70 \mu \mathrm{L})$ before temperature ramping commenced from $27^{\circ} \mathrm{C}$ to $1000{ }^{\circ} \mathrm{C}$ based on the heating rate of $20^{\circ} \mathrm{C} / \mathrm{min}$ under air atmosphere and flow rate $20 \mathrm{~mL} / \mathrm{min}$. The use of air atmosphere was to create an oxidative environment to simulate micro-scale pulverised coal combustion (PCC) and ensure the effective purging of evolved gases during the process. On completion, the TG furnace was cooled to ambient temperature using an automatic air blower. Next, the raw thermogram data were recovered for analysis using the Shimadzu thermal analysis software (Workstation TA-60WS, Japan). The mass loss (TG, \%) and derivative of mass loss (DTG, \%/min) data were subsequently plotted against temperature $\left({ }^{\circ} \mathrm{C}\right.$ ) in Microsoft Excel (version 2013) before further analysis. Based on the plots, the temperature profile characteristics (TPCs) of each coal sample was deduced using the thermal analysis software. For this study, the TPCs deduced were; onset temperature ( $\left.T_{\text {ons }}\right)$, midpoint temperature $\left(T_{\text {mid }}\right)$, maximum peak decomposition temperature $\left(T_{\max }\right)$, offset temperature $\left(T_{o f f}\right)$, mass loss $\left(M_{L}, \%\right)$ and residual mass $\left(R_{M}, \%\right)$. The TPCs provide critical insights into the thermal degradation, potential decomposition yield, and product distribution during thermochemical conversion. 


\subsubsection{Kinetic Analysis}

The kinetic analysis of the coal samples was carried out based on the integral graphical method of the Coats-Redfern Model (CRM). Based on the model, the oxidative thermal decomposition of the coals can be represented by the relations (Coats and Redfern 1964);

$$
\begin{aligned}
& \frac{d x}{d t}=k f(x) \\
& x=\frac{m_{o}-m_{t}}{m_{o}-m_{f}}
\end{aligned}
$$

The terms; $\mathrm{d} x / \mathrm{d} t$ represent the rate of reaction; $k$ is the rate of reaction constant; $f(x)$ is the mechanism of the reaction model, and $x$ is the ratio of the sample masses ( $m_{o}-$ initial; $m_{t}-$ fixed time; and $m_{f}$ - final in $\mathrm{mg}$ ) converted during thermal analysis. The reaction model term for $n$ order of the reaction is given as;

$$
f(x)=(1-x)^{n}
$$

The rate of decomposition of the coal samples and the temperature dependence of the process can be described by the Arrhenius equation;

$$
k(T)=A \exp \left(-\frac{E_{a}}{R T}\right)
$$

The terms $A$ denotes the frequency factor $\left(\mathrm{min}^{-1}\right) ; E_{a}$ is the reaction activation energy $(\mathrm{kJ} / \mathrm{mol}) ; R$ is the molar gas constant $(\mathrm{J} / \mathrm{mol} \mathrm{K})$; and lastly, $T$ is the absolute temperature $(\mathrm{K})$. When the oxidative thermal decomposition process occurs at a fixed heating rate, the term $\beta=$ $\frac{d T}{d t}$ is introduced and substituted into Eq.1 to derive the relation;

$$
\frac{d x}{d T}=\frac{A}{\beta} \exp \left(-\frac{E_{a}}{R T}\right) \cdot(1-x)^{n}
$$

By separation of variables, Eq. 4 can be rearranged to account for the decomposition of the coal materials at a fixed heating rate during TGA and consequently derive the relation;

$$
\frac{d x}{(1-x)^{n}}=\frac{A}{\beta} \exp \left(-\frac{E_{a}}{R T}\right) d \mathrm{~T}
$$

Next, Eq. 6 can be integrated to derive the integral function for the reaction model that describes the thermal decomposition of the coal samples as given by the relation;

$$
g(x)=\int_{0}^{x} \frac{d x}{(1-x)^{n}}=\frac{A}{\beta} \int_{T_{0}}^{T} \exp \left(-\frac{E_{a}}{R T}\right) d \mathrm{~T}
$$

The term $g(x)$ in Eq. 7 represents the integral function of the reaction model that can be used to apply the Coats-Redfern model (CRM). Based on the approximate method of the CRM, the Eq. 7 can be re-written as; 


$$
\ln \left[\frac{g(x)}{T^{2}}\right]=\ln \left[\frac{A R}{\beta E_{a}}\left(1-\frac{2 R T}{E_{a}}\right)\right]-\frac{E_{a}}{R T}
$$

The terms $\ln \left[\frac{A R}{\beta E_{a}}\left(1-\frac{2 R T}{E_{a}}\right)\right]$ in Eq. 8 can be reduced to $\ln \left[\frac{A R}{\beta E_{a}}\right]$ since $\left(1-\frac{2 R T}{E_{a}}\right)$ equates to unity. Hence, Eq. 8 becomes;

$$
\ln \left[\frac{g(x)}{T^{2}}\right]=\ln \left[\frac{A R}{\beta E_{a}}\right]-\frac{E_{a}}{R T}
$$

In this study, the first-order reaction model was selected due to high sample conversion rates during TG analysis. Hence, Eq.9 is modified as;

$$
\ln \left[\frac{-\ln (1-x)}{T^{2}}\right]=\ln \left[\frac{A R}{\beta E_{a}}\right]-\frac{E_{a}}{R T}
$$

The kinetic parameters $E_{a}$ and $A$ can be derived from the slope $-\frac{E_{a}}{R}$ and intercept $\ln \left[\frac{A R}{\beta E_{a}}\right]$ of the straight-line plots of $\ln \left[\frac{-\ln (1-x)}{T^{2}}\right]$ against $\frac{1}{T}$ which is based on the governing mechanism of the thermal degradation reaction. The values of $E_{a}$ and $A$ describe the rate of the thermal reactions, which are dependent on the degree of conversion $(x)$, temperature $(T, \mathrm{~K})$, and time $(t, \mathrm{~min})$ during the TG analysis.

\section{Results and Discussion}

\subsection{Chemical Fuel Properties}

Table 1 shows the chemical fuel properties of the selected Nigerian coals examined in this study. The chemical fuel properties provide valuable insights into the energy recovery potential, emissions characteristics and potential waste profiles of the coals after thermochemical conversion. In this study, the results of the chemical fuel analysis indicate that the coal samples contain high proportions carbon ranging from $61.22 \%$ (LFB) to $73.55 \%$ (CHK) along with oxygen ranging from $18.26 \%$ (CHK) to $30.92 \%$ (OKB). As observed in Table 1, the higher heating value (HHV) of the coal samples occurred between $24.86 \mathrm{MJ} / \mathrm{kg}$ and $30.83 \mathrm{MJ} / \mathrm{kg}$ as observed for OKB and CHK, respectively. The highest HHV observed for CHK is explained by its high carbon but low oxygen and moisture contents. In comparison, the OKB coal highest contents of oxygen and volatile matter among the samples examined in this study. By implication, OKB will exhibit higher thermal reactivity, ignition temperatures, and oxidative degradation due to the impact of its higher oxygen and volatile matter contents compared to LFB and CHK. Consequently, OKB is more suitable for gasification compared to 
the other samples and could potentially yield higher volumes of condensable and noncondensable gases during thermochemical conversion. In contrast, LFB could be more suitable for pyrolysis and CHK for combustion.

The rank and classification of each coal were predicted according to the ASTM standard D388 in the literature (ASTM D388-12 2012). Typically, the standard is employed to predict the rank, classification, and potential application of coal samples based on the HHV, particularly in the absence of petrographic and vitrinite analysis. According to the standard, coals with volatile matter above $31 \mathrm{wt} . \%$ can be ranked or classified accordingly (Speight 2012). Based on the standard, $\mathrm{CHK}(\mathrm{HHV}=30.83 \mathrm{MJ} / \mathrm{kg}$ ) is classified as high-volatile $\mathrm{B}$ bituminous coal with HHV values typically from $30.20 \mathrm{MJ} / \mathrm{kg}$ to $32.60 \mathrm{MJ} / \mathrm{kg}$. The findings for $\mathrm{CHK}$ are in excellent agreement with several authors based on the vitrinite reflectance of $\% \mathrm{R}_{\max } \approx 0.70$ in the literature (Jauro et al. 2008; Akinyemi et al. 2020c). In contrast, LFB (HHV $=26.05 \mathrm{MJ} / \mathrm{kg}$ ) is classified as high-volatile $\mathrm{C}$ bituminous and agglomerating coal with HHV values typically from $30.20 \mathrm{MJ} / \mathrm{kg}$ to $32.60 \mathrm{MJ} / \mathrm{kg}$. However, Akinyemi et al. (2020a) reported that LFB coal is subbituminous based on its vitrinite reflectance of $\% \mathrm{R}_{\max } \approx 0.39$, which contrasts markedly with (Adeyinka and Akinbode 2002; Jauro et al. 2008; Amoo 2015; Oboirien et al. 2018; Akinyemi et al. 2020c) who have reported a similar classification (bituminous coal and $\% \mathrm{R}_{\max } \approx 1.0$ ) as reported in this study. Lastly, OKB (HHV $=24.86 \mathrm{MJ} / \mathrm{kg}$ ) is classified as Subbituminous A and non-agglomerating coal with HHV typically from 24.40 $\mathrm{MJ} / \mathrm{kg}$ to $26.70 \mathrm{MJ} / \mathrm{kg}$ (Speight 2012). The subbituminous nature of OKB in this study is corroborated by the findings of Adeleke et al. (2011) and Oboirien et al. (2018) in the literature. Based on the above criteria, CHK and LFB are considered high-ranked coals, whereas OKB is considered low ranked coal. In addition to the potential applications earlier proposed, CHK and LFB could be also utilised for value-added applications such as the production of metallurgical coke, iron or steel. OKB could be utilised for producing thermal coal or as fuel for industrial thermal processes such as gasification, power generation, or cement production.

Table 1: Chemical Fuel Properties of Selected Nigerian Coals

\subsection{Morphological and Microstructural Properties}

The surface morphology and microstructure of the coal samples were examined by SEM spectroscopy. Figures 1-3 present the high-resolution SEM micrographs of CHK, LFB, and CHK coals examined at a magnification of $\times 2000$. The SEM morphological and microstructural analysis presents valuable insights into the chemical composition, pore 
structure, orientation of particles, and surface composition of solid materials (JEOL 2017; Sengupta et al. 2008). It also provides an indication of the mineral components present in the structure of coals examined during the process (Nyakuma 2019). As observed in Figures 1-3, the morphology of each coal is characterised by a rough, contoured, and compact (or sintered) surface with no evident macro- or micro-pores along despite the heterogeneous sized and shaped particles randomly dispersed on the surfaces. The coal particles observed in the SEM micrographs also exhibited a glassy sheen at the edges and contours, which indicates the presence of mineral or metallic constituents in their structure. The glassy or reflective nature of the surface particles observed on the coal surfaces could be due to the presence of aluminosilicate and iron-containing minerals such as quartz, kaolinite, calcite, and pyrite (Akinyemi et al. 2012; Querol et al. 1995; Liu et al. 2005). The mineralogical analysis of coals in previous studies also detected gypsum, jarosite, montmorillonite and sodium chlorate (Vassileva and Vassilev 2006; Silva et al. 2010; Akinyemi et al. 2020c). The metallic elements $\mathrm{Ti}, \mathrm{Mn}$, and $\mathrm{Fe}$ along with the minerals present in elemental and fused forms are also considered major determinants of surface morphology, thermochemical properties, and quality of the coal (Xu et al. 2019). To examine this, the elemental composition of CHK, LFB, and OKB was examined by EDX spectroscopy as presented in the next section of the paper.

Figure 1: HR-SEM images of Chikila Coal

Figure 2: HR-SEM images of Lafia-Obi Coal

Figure 3: HR-SEM images of Okaba (OKB) Coal

\subsection{Micro-Elemental Properties}

Table 2 shows the micro-elemental composition of the CHK, LFB, and OKB examined by energy-dispersive X-ray (EDX) spectroscopy. The elements detected were; carbon, oxygen, aluminium, silicon, sulphur, calcium, and iron in various quantities. As observed, a total of seven elements (namely; C, O, Al, Si, S, Ca, Fe) were detected in the CHK and LFB coals, although Ca was not detected (ND) in the OKB coal. In this study, the major elements defined as elements with weight per cent (wt.\%) above $1.00 \mathrm{wt} . \%$ are carbon (C) and oxygen (O), whereas the minor (trace wt.\% < 1.00) elements detected were $\mathrm{Al}, \mathrm{Si}, \mathrm{S}, \mathrm{Ca}, \mathrm{Fe}$, and $\mathrm{Ca}$. The metallic elements detected in coal are typically associated with the presence of salts, clay or substituted porphines (or porphyrin rings) (Speight 2012). The metallic element Al indicates the presence of alumina $\left(\mathrm{Al}_{2} \mathrm{O}_{3}\right)$; whereas $\mathrm{Si}$ is ascribed to quartz $\left(\mathrm{SiO}_{2}\right)$, which is regarded as the most abundant mineral on the earth's crust. The presence of $\mathrm{Ca}, \mathrm{Si}$, and $\mathrm{O}$ in combined form could indicate the presence of the calcium ino-silicate mineral $\left(\mathrm{CaSiO}_{3}\right)$ otherwise called 
Wollastonite, whereas $\mathrm{Ca}, \mathrm{C}$ and $\mathrm{O}$ may be due to limestone (calcite) or gypsum $\left(\mathrm{CaSO}_{4} .2 \mathrm{H}_{2} \mathrm{O}\right)$. The presence of limestone (termed coal balls) in coal beds is widely reported in the literature (Scott and Rex 1985; DeMaris 2000). The presence of Al and Si could also be ascribed to the clay (silicate) mineral kaolinite $\left[\mathrm{Al}_{2} \mathrm{Si}_{2} \mathrm{O}_{5}(\mathrm{OH})_{4}\right]$. The elements $\mathrm{Fe}$ and $\mathrm{S}$ indicate the presence of the sulphide mineral pyrite in the coal structure. In general, the EDX analyses revealed the CHK, LFB and OKB coals contain clay and metal-based minerals such as quartz, kaolinite, Wollastonite, gypsum, calcite, kaolinite, and other silicates. This observation denotes the high abundance of clay minerals in the coal samples examined. Other studies have similarly detected the presence of these minerals in coal and coal fly (Luo et al. 2017; Ibarra et al. 1989). According to Barwood et al. (1982), the accurate identification of clay minerals in coals is critical to utilisation during thermochemical conversion such as coal liquefaction. The findings of the study also indicated that the abundance of clay minerals presents crucial information on the environment of coal deposition. Furthermore, the chemical species found in coal are also considered an indication of chemical weathering (Akinyemi et al. 2019; Akinyemi et al. 2020b). It is also a measure of the degree of coalification, rank, and the source coal of mineral matter (Vassilev et al. 1996; Dai et al. 2015; Xu et al. 2019).

Table 2: EDX Elemental Composition of Selected Nigerian Coals

\subsection{Mineralogical Properties}

The mineralogical properties of CHK, LFB and OKB were examined by X-ray fluorescence (XRF) spectroscopy. Table 3 presents the computed mineralogical (metal oxides and non-metallic) compositions of each coal sample in this study. The XRF analysis revealed the presence of 23 major oxides and traces in the CHK and LFB coals, whereas a total of 30 were detected in $\mathrm{OKB}$ coal. The major oxides commonly detected in all the coal samples were; $\mathrm{SiO}_{2}, \mathrm{Al}_{2} \mathrm{O}_{3}, \mathrm{Fe}_{2} \mathrm{O}_{3}, \mathrm{CO}_{2}, \mathrm{MgO}, \mathrm{CaO}, \mathrm{TiO}_{2}, \mathrm{~K}_{2} \mathrm{O}, \mathrm{Na}_{2} \mathrm{O}$ and $\mathrm{SO}_{3}$ corresponding to the oxides of silicon, aluminium, iron, carbon, magnesium, calcium, titanium, potassium, sodium and sulphur. The highest composition of the oxides in the coal samples is due to silicon oxide $\left(\mathrm{SiO}_{2}\right)$ along with the alkali/alkali earth metal oxides $\left(\mathrm{CaO}, \mathrm{Al}_{2} \mathrm{O}_{3}, \mathrm{MgO}, \mathrm{Na}_{2} \mathrm{O}\right.$, and $\left.\mathrm{K}_{2} \mathrm{O}\right)$. The presence of silicon oxide $\left(\mathrm{SiO}_{2}\right)$ and aluminium oxide $\left(\mathrm{Al}_{2} \mathrm{O}_{3}\right)$ indicate the presence of quartz and alumina formed from the $\mathrm{SiO}_{2}-\mathrm{Al}_{2} \mathrm{O}_{3}$ system (Vassilev and Vassileva 1996; Dai et al. 2010) along with kaolinite minerals in the structure of the coals (Liu et al. 2003; Dill et al. 2008). Furthermore, iron oxide $\left(\mathrm{Fe}_{2} \mathrm{O}_{3}\right)$ may be due to the presence of hematite, which is one 
of the most commonly detected minerals in soils and sedimentary rocks (such as shale and coal) formed from weathering processes. The oxide of titanium $\left(\mathrm{TiO}_{2}\right)$ detected in the coal samples may be largely due to ilmenite (manaccanite, $\mathrm{FeTiO}_{3}$ ) and the naturally occurring minerals including rutile and anatase (Zhang et al. 2011; Filippou and Hudon 2009). According to Vassilev and Vassileva (1997), $\mathrm{TiO}_{2}$ could also originate from aragonite, brockite, calcite, iron sulphides, gypsum, mica, oxy-hydroxides and other organic or clay minerals. Lastly, the oxides of carbon $\left(\mathrm{CO}_{2}\right)$ and sulphur $\left(\mathrm{SO}_{3}\right)$ denote the organic nature or history of the coals. In contrast, about 22 oxides of selected metals were detected in minor quantities in the coal samples. Most notably, the $\mathrm{OKB}$ coal was found to contain oxides of $\mathrm{Ga}_{2} \mathrm{O}_{3}, \mathrm{Y}_{2} \mathrm{O}_{3}, \mathrm{Rb}_{2} \mathrm{O}$, $\mathrm{Ar}_{2} \mathrm{O}_{3}, \mathrm{Nb}_{2} \mathrm{O}_{5}, \mathrm{BaO}, \mathrm{La}_{2} \mathrm{O}_{3}, \mathrm{CeO}_{2}, \mathrm{Nd}_{2} \mathrm{O}_{3}, \mathrm{Gd}_{2} \mathrm{O}_{3}, \mathrm{Er}_{2} \mathrm{O}_{3}$, and $\mathrm{WO}_{3}$, which were either detected in trace amounts in LFB or undetected in $\mathrm{CHK}$. The findings indicate that $\mathrm{OKB}$ contains higher concentrations of oxides of alkaline earth $(\mathrm{Ba})$, transition $(\mathrm{Nb})$, rare earth $(\mathrm{Ce}, \mathrm{La}, \mathrm{Nd}, \mathrm{Gd}, \mathrm{Er}$, ) metals and the toxic oxides of the metalloid (Ar). The oxides of the rare earth elements (REE) indicate minerals of organic origins particularly apatite, calcite, feldspars, iron sulphides, mica, monazite, siderite, xenotime, and zircon (Vassilev and Vassileva 1997). The higher concentrations of the REE detected in the study also reveals the level weathering, maturity, rank and classification of the coals. Based on the findings, the rank of the coals is in the order $\mathrm{CHK}>\mathrm{LFB}>\mathrm{OKB}$, which is in good agreement with earlier submission based on ASMT D388. The concentrations of the REE and other elements in OKB conforms its low-rank status compared to LFB and CHK, which suggests higher thermal reactivity or degradation during thermal conversion processes. Hence, the thermal degradation behaviour, decomposition pathways, and temperature profile characteristics of the coals are presented in the next section.

Table 3: XRF Compositions of Nigerian Coals

\subsection{Thermochemical Properties}

Figures 4 and 5 show the thermogravimetric (TG) and derivative (DTG) plots for the CHK, LFB, and OKB coal samples. As shown in Figure 4, the non-isothermal heating programme resulted in the rapid thermal degradation of the coal samples as evident in the downward $\mathrm{Z}$ shape curves. These observations indicate the process resulted in a significant mass loss $\left(M_{L}>90 \%\right)$ and lower residual masses $\left(R_{M}\right)$ for each sample. The mass loss during TGA of the coals could be ascribed to the loss of volatile organic components or macerals in the structure of the coals. The organic components of coal are typically comprised of inertinite, vitrinite, and liptinite groups (Speight 2012). Based on the rank, classification, and source of 
the coal the proportion of each organic components can range from 5-10\% for liptinite, 50$90 \%$ for vitrinite, and $50-70 \%$ for inertinite. The thermochemical reactivity along with the yield and distribution of products from coal conversion is largely influenced by the proportion of macerals (Landais et al. 1989; Košina and Heppner 1984), particularly vitrinite and inertinite fractions (Zhao et al. 2011). The loss of mass during coal degradation could also be attributed to the degradation of lignocellulosic materials (resins, cellulose, lignin) originating from plants during the coalification process (Xie et al. 2013; Sun et al. 2003). The effect of the thermal degradation process on the mass loss $\left(M_{L}\right)$, residual mass $\left(R_{M}\right)$ and the corresponding temperature profile characteristics of the coals are presented in Table 4. The TPCs deduced in this study are; the onset $\left(T_{\text {ons }}\right)$, midpoint $\left(T_{\text {mid }}\right)$, and offset $\left(T_{\text {off }}\right)$ temperatures.

Figure 4: TG Plots for Oxidative TG Coal Analysis

Table 4: Coal Characteristic Temperature and Mass Loss Profiles

The results indicate that the mass loss $\left(M_{L}, \%\right)$ was in the range $91.59-94.04 \%$, whereas the residual mass $\left(R_{M}, \%\right)$ was from $5.96-8.41 \%$ for the coals. The $M_{L}$ is in the order LFB > $\mathrm{OKB}>\mathrm{CHK}$, whereas the $R_{M}$ is in the reverse order $\mathrm{CHK}>\mathrm{OKB}>\mathrm{LFB}$. Based on the findings, LFB experienced the highest mass loss $\left(M_{L}, \%\right)$ along with the lowest residual mass $\left(R_{M}, \%\right)$, which indicates it is more thermally reactive when compared to OKB and CHK. In contrast, CHK was the least thermally reactive as it experienced the lowest mass loss $\left(M_{L}, \%\right)$ but the highest residual mass $\left(R_{M}, \%\right)$. The findings indicate that LFB and OKB are lower in rank compared to CHK due to their higher reactivity during TGA. Typically, low ranked coals exhibit high thermal reactivity due to the presence of inert components and non-coking properties (Gomes et al. 2006). Furthermore, the structure of low ranked coals contains highly reactive functional groups, higher contents of $\mathrm{H}$ and $\mathrm{O}$, along with higher pores and surface area compare to coals of higher ranks (Kim et al. 2015). Hence, the higher contents of rare earth and alkali/alkali earth metals of LFB and OKB (as earlier surmised in Table 3) may account for the higher mass loss of the coals. The high reactivity of low-rank coals accounts particularly at low temperatures can result in spontaneous combustion, thereby posing human safety and environmental risks during storage (Kim et al. 2015). Hence, the TGA results also provide valuable insights into the health and safety of coal storage and utilization.

The TPCs also showed that thermal degradation revealed distinct values of onset $\left(T_{\text {ons }}\right)$, midpoint $\left(T_{m i d}\right)$, and offset $\left(T_{o f f}\right)$ temperatures for each coal examined. The analysis indicated that the onset $\left(T_{\text {ons }}\right)$ ranged from $321.70{ }^{\circ} \mathrm{C}$ to $394.94{ }^{\circ} \mathrm{C}$, whereas the midpoint $\left(T_{m i d}\right)$, was 
from $436.77^{\circ} \mathrm{C}$ to $530.54{ }^{\circ} \mathrm{C}$ and the offset $\left(T_{\text {off }}\right)$ was from $548.58{ }^{\circ} \mathrm{C}$ to $657.27^{\circ} \mathrm{C}$. The findings indicate that the CHK exhibited the highest onset $\left(T_{\text {ons }}\right)$, midpoint $\left(T_{m i d}\right)$, and offset $\left(T_{\text {off }}\right)$ values of $394.94{ }^{\circ} \mathrm{C}, 530.54{ }^{\circ} \mathrm{C}$, and $657.27{ }^{\circ} \mathrm{C}$, respectively, whereas the lowest values were observed for OKB. This observation confirms that $\mathrm{CHK}$ is more thermally stable compared to the lowerranked OKB and LFB coals examined in this study. Further studies to examine the thermal reactivity of the coal samples through derivative thermal analysis (DTG). The DTG against temperature plots for $\mathrm{CHK}, \mathrm{LFB}$, and $\mathrm{OKB}$ are presented in Figure 5. The plots show several endothermic peaks of various sizes and shapes resulting from the thermal degradation process. The first set of small yet symmetric peaks can be observed from RT to $200{ }^{\circ} \mathrm{C}$ for all the coal samples. Based on the mass losses; CHK (3.483 wt.\%), LFB (11.732 wt.\%) and OKB (9.587 wt.\%) or $M_{L}<12$ wt.\% during this stage, the thermal degradation could be ascribed to the loss of moisture and low molecular weight volatile coal components.

Figure 5: DTG Plots for Oxidative TG Coal Analysis

The second stage is characterised by a larger set of asymmetric peaks compared to the first stage and was observed between $200{ }^{\circ} \mathrm{C}$ and $650{ }^{\circ} \mathrm{C}$ for OKB and LFB whereas it was 700 ${ }^{\circ} \mathrm{C}$ for $\mathrm{CHK}$. The mass loss during this stage is due to the thermal degradation of macerals notably the inertinite and vitrinite fractions of the coals (Zhao et al. 2011). Based on the findings $\mathrm{CHK}$ requires a higher temperature range for thermal degradation compared to LFB and $\mathrm{OKB}$, which further emphasises it is a higher-ranked coal. Table 5 presents the characteristic of coal TPCs for DTG plots and mass-loss rates. The characteristic coal TPCs deduced from the DTG peaks showed that the maximum temperatures for drying occurred between $60.40{ }^{\circ} \mathrm{C}(\mathrm{CHK})$ and $89.51{ }^{\circ} \mathrm{C}(\mathrm{OKB})$, whereas the drying rates $(\% / \mathrm{min})$ were observed from $1.04 \% / \mathrm{min}$ to $2.88 \% / \mathrm{min}$. The results further indicate the drying rate of LFB was the highest of the coals examined in this study, which could be ascribed to its high moisture content (10.81 wt.\%) compared to OKB and CHK. As earlier surmised, the second stage of the TGA process was characterised by a larger asymmetric peak culminating in maximum value termed the devolatilization peak temperature $\left(T_{d e v},{ }^{\circ} \mathrm{C}\right)$. In this study, the $T_{d e v}$ was observed from $428.46{ }^{\circ} \mathrm{C}(\mathrm{LFB})$ to the highest value of $517.61{ }^{\circ} \mathrm{C}(\mathrm{CHK})$. The high $T_{d e v}$ is related to the effect of volatile matter (VM), which accounts for the thermal ignition and reactivity of carbonaceous materials (Basu 2010). As reported in Table 1, the volatile matter of CHK is 54.41 wt.\% which is lower than LFB (58.95 wt.\%), and OKB (61.99 wt.\%). Hence, the high $T_{d e v}$ value of CHK is explained by its comparatively lower VM, which accounts for its higher 
ignition temperature $\left(T_{\text {ons }}=394.94{ }^{\circ} \mathrm{C}\right)$ reported in Table 4. Likewise, $\mathrm{CHK}$ has the lowest reactivity (due to its low VM and high ranked nature) as evident in its low devolatilization rate of $7.17 \% / \mathrm{min}$ compared to $7.70 \% / \mathrm{min}$ for LFB and $7.89 \% / \mathrm{min}$ for OKB. The thermal reactivity of the coals was further examined by kinetic analysis.

Table 5: Characteristic Coal TPCs for DTG Plots and Mass Loss Rates

\subsection{Kinetic Properties}

The kinetic parameters; activation energy $\left(E_{a}, \mathrm{~kJ} / \mathrm{mol}\right)$ and frequency factor $\left(A, \min ^{-1}\right)$ was computed based on the governing equations of the Coats-Redfern Model (CRM). The $E_{a}$ and $A$ were calculated from the slope and intercept of the downward sloping kinetic plots in Figure 6. For the coal samples examined in this study, the value was computed as presented in Table 6. The $E_{a}$ values range from $30.07 \mathrm{~kJ} / \mathrm{mol}$ to $43.91 \mathrm{~kJ} / \mathrm{mol}$, whereas $A$ is from $1.16 \times 10^{-}$ $02 \mathrm{~min}^{-1}$ to $6.73 \times 10^{-02} \mathrm{~min}^{-1}$ with the minima and maxima ascribed to LFB and CHK, respectively. The results indicate that the thermal degradation of the coals is highly reactive as evident in the low values of $E_{a}$ and $A$ in Table 6, which were computed at high $\mathrm{R}^{2}$ values of 0.98-0.99. Furthermore, the findings confirm that LFB is more thermally reactive when compared to the $\mathrm{OKB}$ and $\mathrm{CHK}$ in decreasing order. In comparison, Sonibare et al. (2005) reported that the oxidative thermal analysis of selected coals from Nigeria are; $E_{a}$ of 68.50 $\mathrm{kJ} / \mathrm{mol}-90.90 \mathrm{~kJ} / \mathrm{mol}, A$ of $4.3 \times 10^{01} \mathrm{~min}^{-1}-6.7 \times 10^{02} \mathrm{~min}^{-1}$, and $R^{2}$ of $0.980-0.994$. Hence, the values of $\mathrm{CHK}, \mathrm{LFB}$, and $\mathrm{OKB}$ in this study differ markedly from the findings from Sonibare et al. (2005). The differences could be ascribed to the variable physicochemical, macerals composition, rank classification, and reactivity of the coals.

Figure 6: CRM Kinetic Plots for Thermal Degradation of Benue Trough Coals

Table 6: Calculated Kinetic Properties of Coals based on Coats-Redfern Model (CRM)

\section{Conclusion}

The geomineralogical, physiochemical, thermal and kinetic fuel properties of selected coal samples from the Benue Trough and Anambra Basins of Nigeria were comprehensively examined in this study. The physicochemical characterisation revealed high compositions of carbon, volatile matter, fixed carbon but relatively low moisture, and ash. The calorific analysis revealed high heating values $(25-30 \mathrm{MJ} / \mathrm{kg})$ indicating mid-to-high ranked subbituminous 
and bituminous coals. The surface morphology and microstructure revealed randomly dispersed coal particles with a glassy sheen, heterogeneous sizes, and shapes, as observed in the SEM/EDX analyses. Based on the mineralogical analysis, the oxides of silicon, aluminium, iron, carbon, magnesium, calcium, titanium, potassium, sodium and sulphur were detected in major quantities along with minor quantities of 22 other metals and non-metal elements. The findings indicate the presence of alkali/alkali earth metal oxides along with aluminosilicate and clay minerals such as quartz, alumina, kaolinite, and hematite. The thermal analysis examined under oxidative environment revealed high mass loss $\left(M_{L}=91.59-94.04 \%\right)$ but low mass of residuals $\left(R_{M}=5.96 \%-8.41 \%\right)$ for each sample. The high thermal degradation behaviour and mass-loss rates could be ascribed to devolatilization and maceral decomposition of the coals. Kinetic analysis showed that the selected coal samples are highly reactive as evident in the low values of $E_{a}$ and $A$ computed at high $\mathrm{R}^{2}$ values of 0.98-0.99 using the Coats-Redfern Model (CRM). Overall, the findings indicate that the selected coal samples have a high potential for energy recovery by oxidative conversion technologies such as pulverised coal combustion.

\section{Availability of data and materials}

All the data in the manuscript is presented in the form of tables and figures.

\section{Competing interests}

The authors declare that there are no competing interests whatsoever for the study reported in this manuscript.

\section{Funding}

This research did not receive any form of funding or financial support from any organisation.

\section{Authors' contributions}

Bemgba B. Nyakuma - Original Manuscript draft; Aliyu Jauro - Writing Review Revisions, Editing, \& Proofing; Segun A. Akinyemi - Editing, Conceptualisation \& Coal Procurement; Syie L. Wong - Manuscript Review, Editing, \& Proofing; Olagoke Oladokun - Experimental Design, Methodology \& Data Analysis; Tuan Amran T. Abdullah - Supervision, FactChecking, Editing, \& Proofing. 


\section{Acknowledgements}

The authors wish to acknowledge the Hydrogen Fuel Cell at Universiti Teknologi Malaysia (UTM) for the TGA runs. Many thanks also accrue to Universiti Malaysia Pahang (UMP) for the technical assistance with the XRF. The surface analysis (SEM/EDX) section of the University Industrial Research Laboratory (UiRL, UTM) is also gratefully acknowledged.

\section{References}

Adeleke A, Onumanyi P, Ibitoye S (2011) Mathematical optimization of non-coking coal inclusion in coking blend formulations Petroleum \& Coal 53:1-8

Adewuyi OB, Lotfy ME, Akinloye BO, Howlader HOR, Senjyu T, Narayanan K (2019) Security-constrained optimal utility-scale solar PV investment planning for weak grids: Short reviews and techno-economic analysis Applied Energy 245:16-30

Adeyinka JS, Akinbode F (2002) Gasification of Nigerian bituminous coal in a shallow bed

Akinyemi S, Gitari W, Akinlua A, Petrik L (2012) Mineralogy and geochemistry of subbituminous coal and its combustion products from Mpumalanga Province, South Africa. In: Analytical Chemistry. InTech,

Akinyemi SA, Adebayo OF, Nyakuma BB, Adegoke AK, Aturamu OA, OlaOlorun OA, Adetunji A, Hower JC, Hood MM, Jauro A (2020a) Petrology, physicochemical and thermal analyses of selected cretaceous coals from the Benue Trough Basin in Nigeria International Journal of Coal Science \& Technology 7:26-42 doi:10.1007/s40789-02000303-6

Akinyemi SA, Gitari WM, Petrik LF, Nyakuma BB, Hower JC, Ward CR, Oliveira MLS, Silva LFO (2019) Environmental evaluation and nano-mineralogical study of fresh and unsaturated weathered coal fly ash Science of The Total Environment 663:177-188 doi:https://doi.org/10.1016/j.scitotenv.2019.01.308

Akinyemi SA, Gitari WM, Thobakgale R, Petrik LF, Nyakuma BB, Hower JC, Ward CR, Oliveira MLS, Silva LFO (2020b) Geochemical fractionation of hazardous elements in fresh and drilled weathered South African coal fly ashes Environmental Geochemistry and Health doi:10.1007/s10653-019-00511-3

Akinyemi SA, Nyakuma BB, Jauro A, Adebayo OF, OlaOlorun OA, Adegoke AK, Aturamu AO, Adetunji A, Gitari WM, Mudzielwana R (2020c) Mineralogy, physicochemical and oxidative thermal analyses of Cretaceous coals from the Benue Trough, Nigeria Energy Geoscience:1-7 doi:https://doi.org/10.1016/j.engeos.2020.07.001

Aliyu AS, Ramli AT, Saleh MA (2013) Nigeria electricity crisis: Power generation capacity expansion and environmental ramifications Energy 61:354-367

Amoo LM (2015) Computational fluid dynamics simulation of Lafia-Obi bituminous coal in a fluidized-bed chamber for air-and oxy-fuel combustion technologies Fuel 140:178191

ASTM D388-12 (2012) Standard classification of coals by rank. ASTM International, West Conshohocken, PA, USA

Barwood HL, Curtis CW, Guin JA, Tarrer AR (1982) Identification of clay minerals in coal by selective cation saturation Fuel 61:463-469 
Basu P (2010) Biomass Gasification and Pyrolysis: Practical Design and Theory. Academic Press (Elsevier), Burlington MA, USA

Benkhelil J (1989) The origin and evolution of the Cretaceous Benue Trough (Nigeria) Journal of African Earth Sciences (and the Middle East) 8:251-282

Burke K (1996) The African Plate South African Journal of Geology 99:341-409

Chukwu M, Folayan C, Pam G, Obada D (2016) Characterization of some Nigerian coals for power generation Journal of Combustion 2016

Coats AW, Redfern JP (1964) Kinetic Parameters from Thermogravimetric Data Nature 201:68-69 doi:10.1038/201068a0

Dai S, Li T, Jiang Y, Ward CR, Hower JC, Sun J, Liu J, Song H, Wei J, Li Q (2015) Mineralogical and geochemical compositions of the Pennsylvanian coal in the Hailiushu Mine, Daqingshan Coalfield, Inner Mongolia, China: Implications of sediment-source region and acid hydrothermal solutions International Journal of Coal Geology 137:92-110

Dai S, Zhao L, Peng S, Chou C-L, Wang X, Zhang Y, Li D, Sun Y (2010) Abundances and distribution of minerals and elements in high-alumina coal fly ash from the Jungar Power Plant, Inner Mongolia, China International Journal of Coal Geology 81:320-332 doi:https://doi.org/10.1016/j.coal.2009.03.005

DeMaris PJ (2000) Formation and distribution of coal balls in the Herrin coal (Pennsylvanian), Franklin County, Illinois Basin, USA Journal of the Geological Society 157:221-228

Dill H, Kus J, Dohrmann R, Tsoy Y (2008) Supergene and hypogene alteration in the dual-use kaolin-bearing coal deposit Angren, SE Uzbekistan International Journal of Coal Geology 75:225-240

Donahue CJ, Rais EA (2009) Proximate Analysis of Coal Journal of Chemical Education 86:222 doi:10.1021/ed086p222

Ehinola OA, Ekweozor C, Oros D, Simoneit B (2002) Geology, geochemistry and biomarker evaluation of Lafia-Obi coal, Benue Trough, Nigeria Fuel 81:219-233

Emodi NV (2016) The Energy Sector in Nigeria. In: Energy Policies for Sustainable Development Strategies. Springer, pp 9-67

Emodi NV, Yusuf SD (2015) Improving electricity access in Nigeria: obstacles and the way forward International Journal of Energy Economics and Policy 5:335-351

Emovon I, Samuel OD, Mgbemena CO, Adeyeri MK (2018) Electric Power generation crisis in Nigeria: A Review of causes and solutions International Journal of Integrated Engineering 10

Filippou D, Hudon G (2009) Iron removal and recovery in the titanium dioxide feedstock and pigment industries JOM 61:36

Gomes MdLI, Osório E, Vilela ACF (2006) Thermal analysis evaluation of the reactivity of coal mixtures for injection in the blast furnace Materials Research 9:91-95

Gräbner M (2014) Industrial coal gasification technologies covering baseline and high-ash coal. John Wiley \& Sons, United States of America

Hoque M, Nwajide C (1984) Tectono-sedimentological evolution of an elongate intracratonic basin (aulacogen): The case of the Benue Trough of Nigeria Nigerian Journal of Mineral Geology 21:19-26

Ibarra J, Palacios J, de Andrés AM (1989) Analysis of coal and char ashes and their ability for sulphur retention Fuel 68:861-867

IEA-CCC (2020) Cambodia: Two Coal Power Plants Built In Preah Sihanouk. IEA Clean Coal Centre. https://bit.ly/2PYsJpT. Accessed 8th March 2020

IEA-OECD (2002) Coal in the energy supply of India Energy Indicators 1:1-30

IEA (2012) The Global Value of Coal, 1st Edn. International Energy Agency Paris, France. doi:doi:https://doi.org/10.1787/5k9gshqcdshl-en 
IEA (2020) Global coal demand by forecast for 2000-2024. International Energy Agency. https://bit.ly/2Q4Wbdn. Accessed 08 August 2020

Jauro A, Chigozie A, Nasirudeen M (2008) Determination of selected metals in coal samples from Lafia-Obi and Chikila Science World Journal 3

JEOL (2017) JEOL-JSM IT 300 LV SEM Microscope. JEOL Germany. http://bit.ly/2khv3uX. Accessed 4th December 2017

Kim J, Lee Y, Ryu C, Park HY, Lim H (2015) Low-temperature reactivity of coals for evaluation of spontaneous combustion propensity Korean journal of chemical engineering 32:1297-1304

Košina M, Heppner P (1984) Macerals in bituminous coals and the coking process: Part 1: Effect of basic coal properties on the process of thermal degradation Fuel 63:838-846

Landais P, Muller J-F, Michels R, Oudin J-L, Zaugg P (1989) Comparative behaviour of coal and maceral concentrates during artificial coalification Fuel 68:1616-1619

Liu G, Vassilev SV, Gao L, Zheng L, Peng Z (2005) Mineral and chemical composition and some trace element contents in coals and coal ashes from Huaibei coal field, China Energy Conversion and Management 46:2001-2009

Liu X, Yan Z, Wang H, Luo Y (2003) In situ synthesis of NaY zeolite with coal-based kaolin Journal of Natural Gas Chemistry 12:63-70

Luo Y, Ma S, Zhao Z, Wang Z, Zheng S, Wang X (2017) Preparation and characterization of whisker-reinforced ceramics from coal fly ash Ceramics International 43:1-11

Maluski H, Coulon C, POPOFF Mt, Baudin P (1995) 40Ar/39Ar chronology, petrology and geodynamic setting of Mesozoic to early Cenozoic magmatism from the Benue Trough, Nigeria Journal of the Geological Society 152:311-326

Miller BG (2016) Clean Coal Engineering Technology vol 2. Technology \& Engineering. Butterworth-Heinemann (Elsevier Science), Oxford, United Kingdom

Mining Technology (2020) Countries with the biggest coal reserves. Mining Technology Press. https://bit.ly/3ghcezC. Accessed 18th August 2020

Mohammed Y, Mustafa M, Bashir N, Mokhtar A (2013) Renewable energy resources for distributed power generation in Nigeria: a review of the potential Renewable and Sustainable Energy Reviews 22:257-268

Musa D (2010) The economics of electric power supply in Nigeria. Gamji. https://bit.ly/2YeoLgU. Accessed 12th April 2020

Nerini FF, Broad O, Mentis D, Welsch M, Bazilian M, Howells M (2016) A cost comparison of technology approaches for improving access to electricity services Energy 95:255265

Nwajide CS, Reijers TJA (1996) The Geology of the southern Anambra Basin: sedimentary geology, and sequence stratigraphy of the Anambra Basin Geology:133-148.

Nyakuma BB (2019) Physicochemical, Geomineralogical, and Evolved Gas Analyses of Newly Discovered Nigerian Lignite Coals Coke \& Chemistry 62:394-401

Obaje NG (2009) Geology and mineral resources of Nigeria vol 120. Lecture Notes in Earth Sciences. Springer, Berlin, Heidelberg, Berlin, Germany. doi:https://doi.org/10.1007/978-3-540-92685-6

Oboirien B, North BC, Obayopo S, Odusote J, Sadiku E (2018) Analysis of clean coal technology in Nigeria for energy generation Energy Strategy Reviews 20:64-70

Odunze SO, Obi GC, Yuan W, Min L (2013) Sedimentology and sequence stratigraphy of the Nkporo Group (Campanian-Maastrichtian), Anambra Basin, Nigeria Journal of Palaeogeography 2:192-208 doi:https://doi.org/10.3724/SP.J.1261.2013.00026

Offodile M (1980) A mineral survey of the Cretaceous of the Benue Valley, Nigeria Cretaceous Research 1:101-124 
Offodile ME (1976) The geology of the middle Benue Nigeria vol 4. Stratigraphy, Palaeontology, \& Hydrography. Paleontological Institute, University of Uppsala, Uppsala, Sweden

Ohimain EI (2014) Can Nigeria generate 30\% of her electricity from coal? International Journal of Energy and Power Engineering 3:28-37

Olade M (1975) Evolution of Nigeria's Benue Trough (Aulacogen): a tectonic model Geological Magazine 112:575-583

Oseni MO (2011) An analysis of the power sector performance in Nigeria Renewable and Sustainable Energy Reviews 15:4765-4774

Oyedepo SO (2014) Towards achieving energy for sustainable development in Nigeria Renewable and Sustainable Energy Reviews 34:255-272

Petters SW (1982) Central West African Cretaceous-Tertiary benthic foraminifera and stratigraphy Palaeontographica Abteilung A:1-104

Querol X, Fernández-Turiel J, López-Soler A (1995) Trace elements in coal and their behaviour during combustion in a large power station Fuel 74:331-343

Sambo A Prospect of coal for power generation in Nigeria. In: A paper presented at the International Workshop for the Promotion of Coal for Power Generation, 2009. pp 2728

Sambo AS, Garba B, Zarma IH, Gaji MM (2012) Electricity generation and the present challenges in the Nigerian power sector Journal of Energy and Power Engineering 6:1050-1059

Scott A, Rex G (1985) The formation and significance of Carboniferous coal balls Philosophical Transactions of the Royal Society of London B, Biological Sciences 311:123-137

Sengupta P, Saikia PC, Borthakur PC (2008) SEM-EDX characterization of an iron-rich kaolinite clay Journal of Scientific and Research 67:812-818

Silva LF, Ward CR, Hower JC, Izquierdo M, Waanders F, Oliveira ML, Li Z, Hatch RS, Querol X (2010) Mineralogy and leaching characteristics of coal ash from a major Brazilian power plant Coal Combustion and Gasification Products 2:51-65

Sonibare O, Ehinola O, Egashira R, KeanGiap L (2005) An investigation into the thermal decomposition of Nigerian Coal Journal of Applied Sciences 5:104-107

Speight JG (2012) The Chemistry and Technology of Coal. Chemical Industries, Third Edition Edn. CRC Press, USA

Speight JG (2013) Coal-fired power generation handbook vol 1. Technology \& Engineering: Power Generation. John Wiley \& Sons, United States of America

Sun Q-L, Li W, Chen H-K, Li B-Q (2003) TG-MS study on pyrolysis behaviour of Shenmu coal macerals Journal of China University of Mining \& Technology 32:664-669

Vassilev SV, Kitano K, Vassileva CG (1996) Some relationships between coal rank and chemical and mineral composition Fuel 75:1537-1542

Vassilev SV, Vassileva CG (1996) Mineralogy of combustion wastes from coal-fired power stations Fuel Processing Technology 47:261-280

Vassilev SV, Vassileva CG (1997) Geochemistry of coals, coal ashes and combustion wastes from coal-fired power stations Fuel Processing Technology 51:19-45 doi:https://doi.org/10.1016/S0378-3820(96)01082-X

Vassileva CG, Vassilev SV (2006) Behaviour of inorganic matter during heating of Bulgarian coals: 2. Subbituminous and bituminous coals Fuel Processing Technology 87:10951116

World Coal Association (2017) Basic coal facts. World Coal Association (WCA). https://bit.ly/3iOrPbe. Accessed 8th August 2020 
Xie W, Stanger R, Lucas J, Wall T, Mahoney M (2013) Coal macerals separation by reflux classification and thermo-swelling analysis based on the Computer-Aided Thermal Analysis Fuel 103:1023-1031

Xu Y, Liang H, Zhang N (2019) Mineralogical characteristics and sources of alkali metals in the No. 6 coal seam from the Fukang mining area of the Zhunnan coalfield, Xinjiang province, Northwest China Energy Exploration \& Exploitation 37:1162-1181

Zaborski P, Ugodulunwa F, Idornigie A, Nnabo P, Ibe K (1997) Stratigraphy and structure of the Cretaceous Gongola Basin, northeast Nigeria Bulletin des Centres de Recherches Exploration-Production Elf Aquitaine 21:153-185

Zhang W, Zhu Z, Cheng CY (2011) A literature review of titanium metallurgical processes Hydrometallurgy 108:177-188

Zhao Y, Hu H, Jin L, He X, Wu B (2011) Pyrolysis behaviour of vitrinite and inertinite from Chinese Pingshuo coal by TG-MS and in a fixed bed reactor Fuel Processing Technology 92:780-786 
Figures

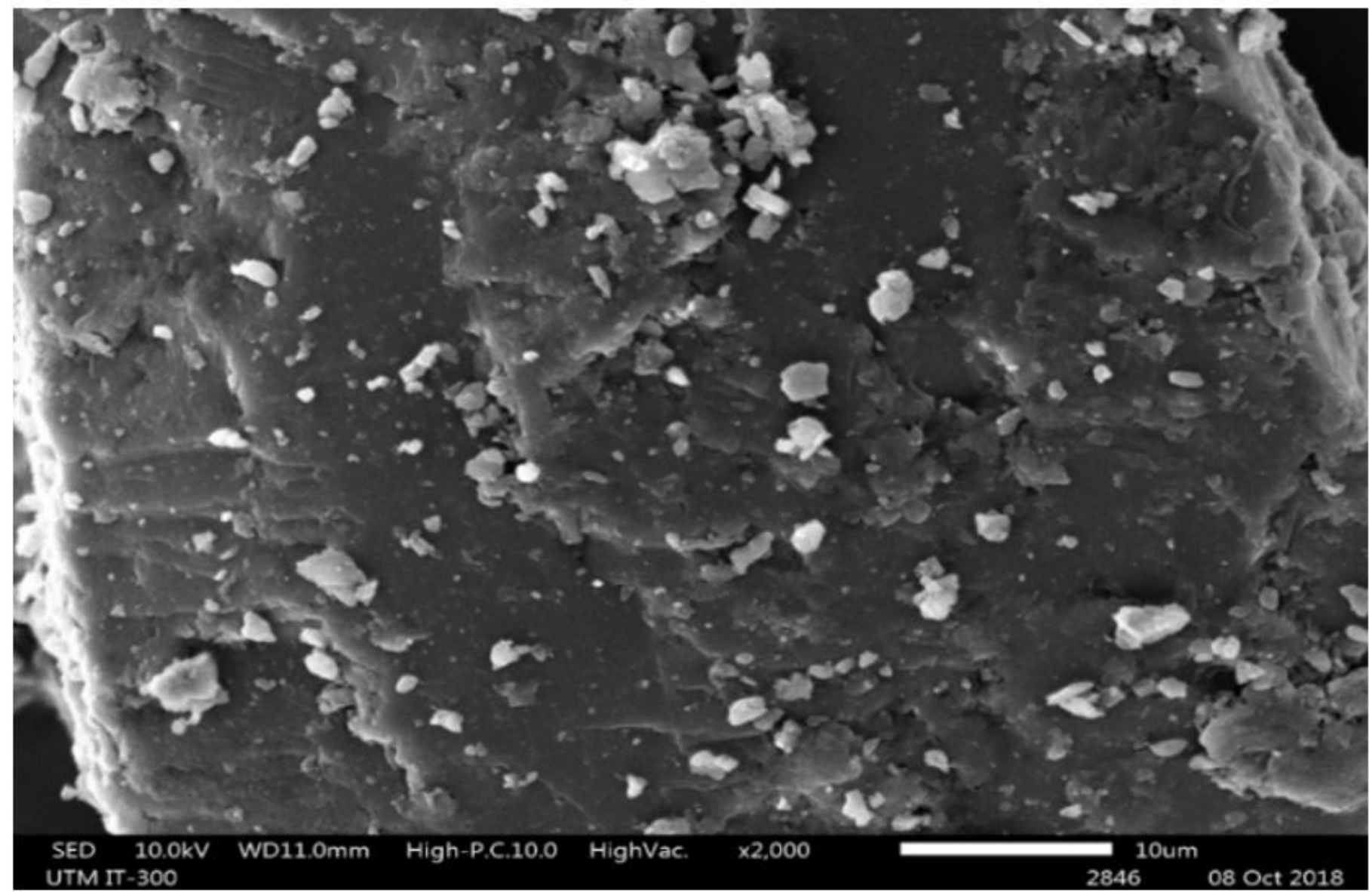

Figure 1

HR-SEM images of Chikila Coal 


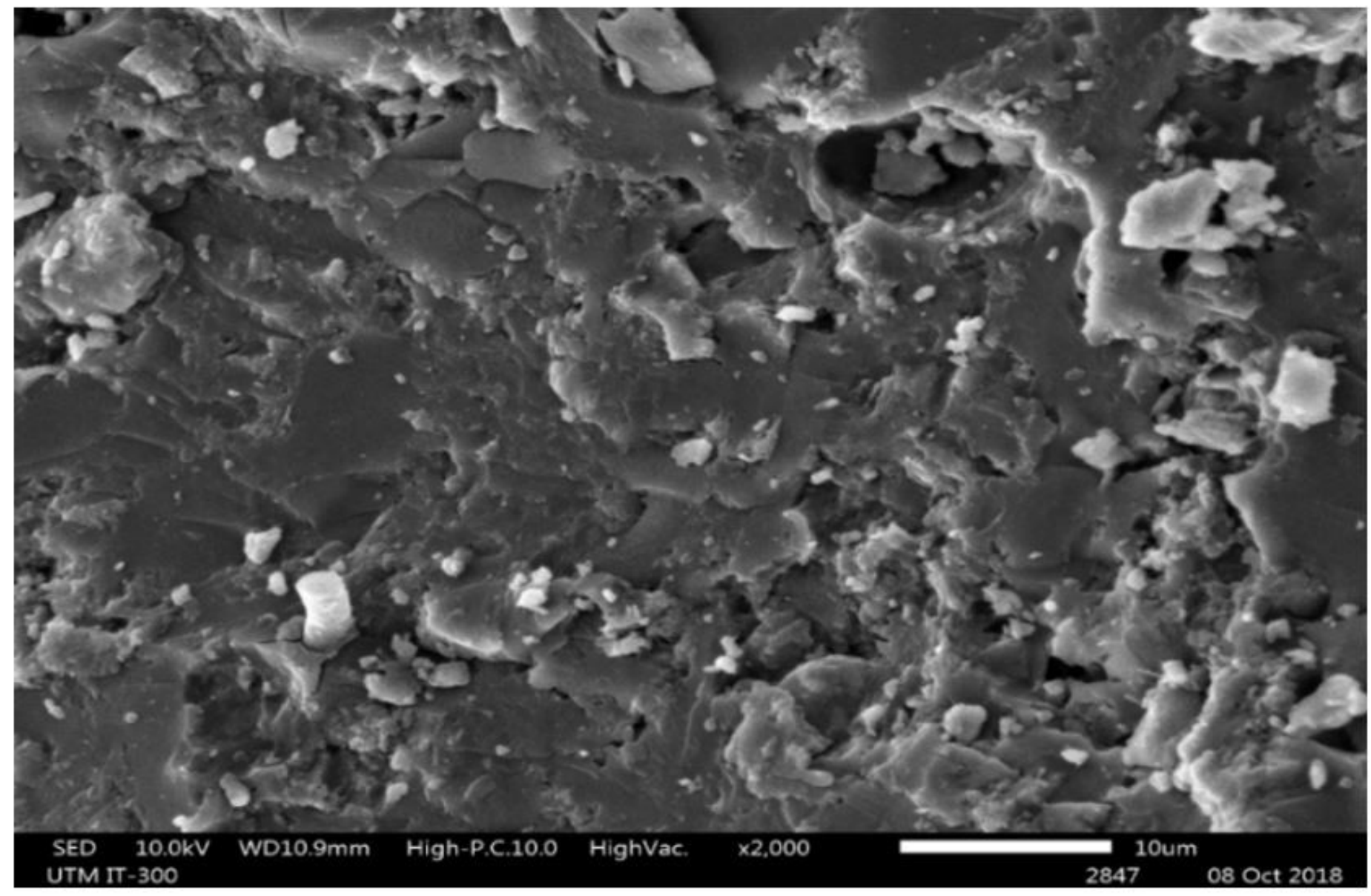

Figure 2

HR-SEM images of Lafia-Obi Coal 


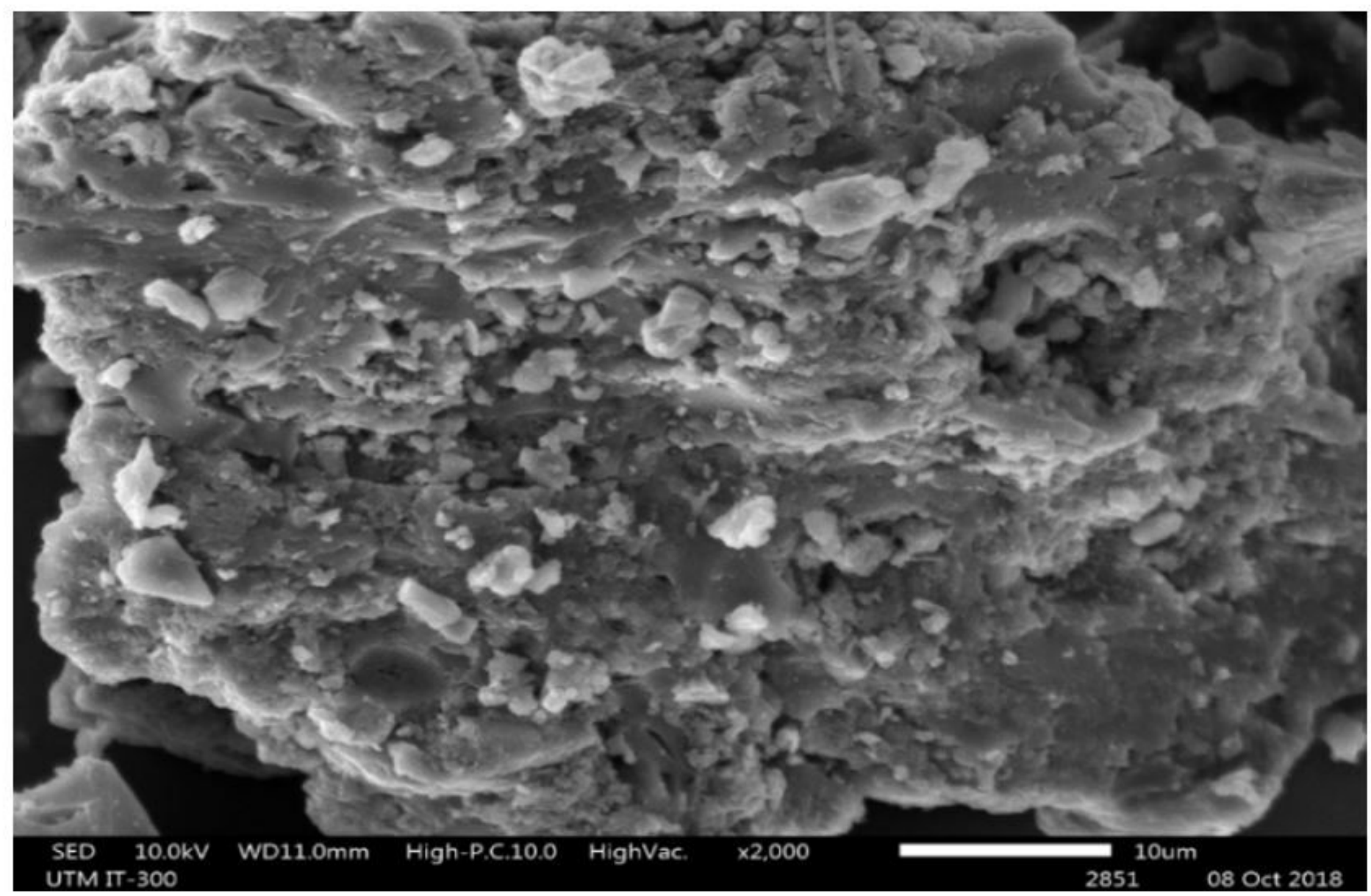

Figure 3

HR-SEM images of Okaba (OKB) Coal 


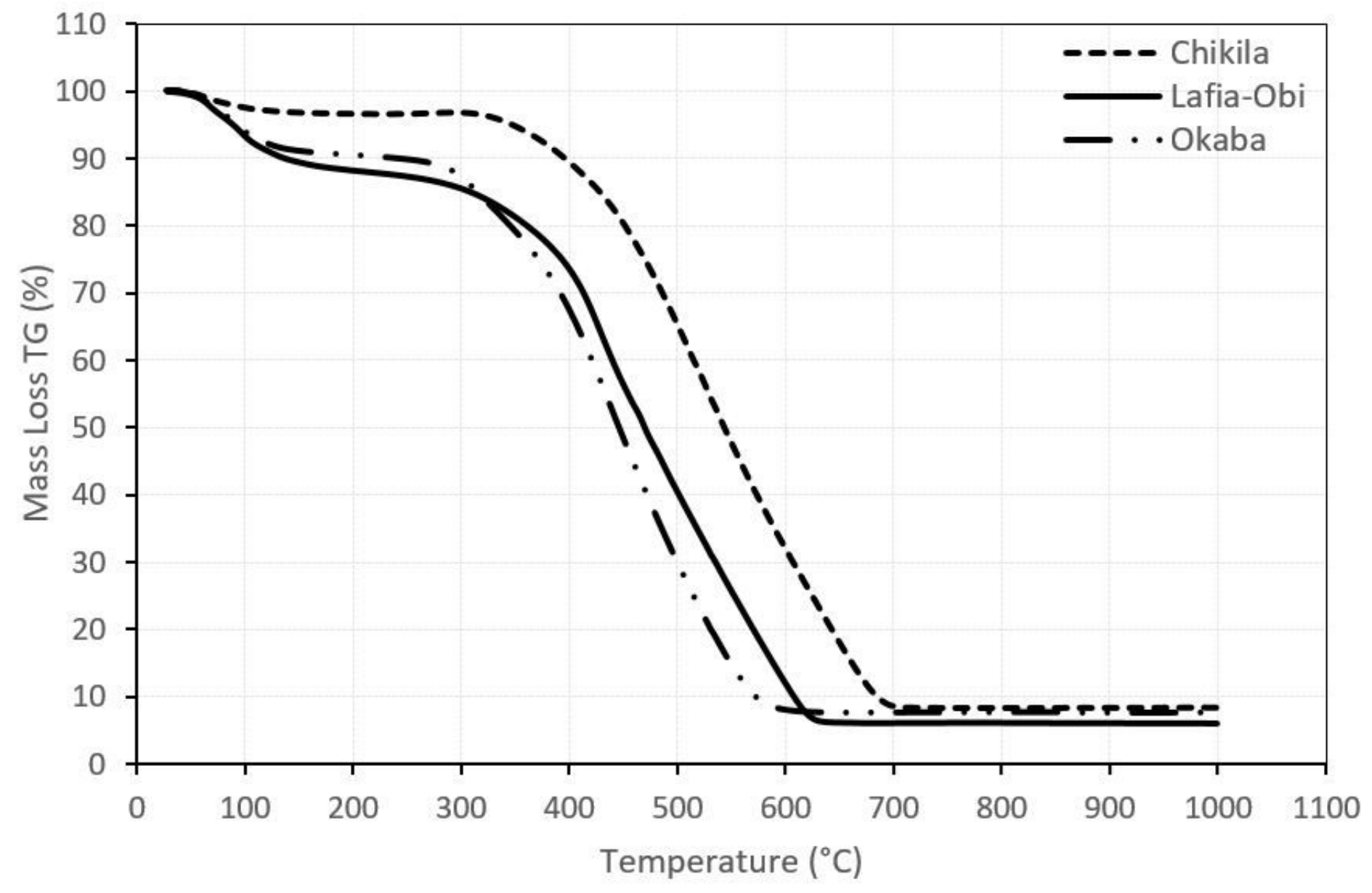

Figure 4

TG Plots for Oxidative TG Coal Analysis 


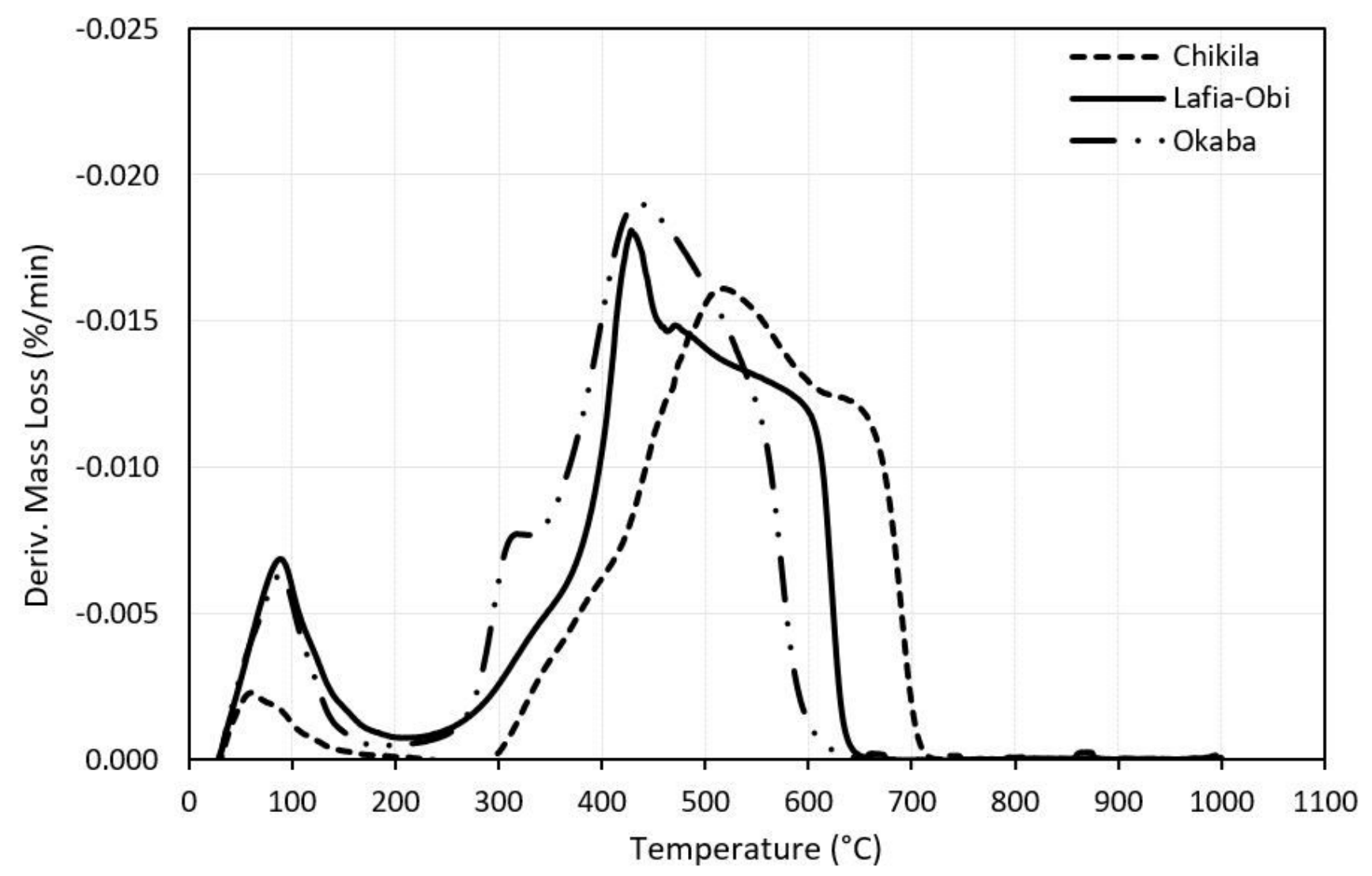

Figure 5

DTG Plots for Oxidative TG Coal Analysis 


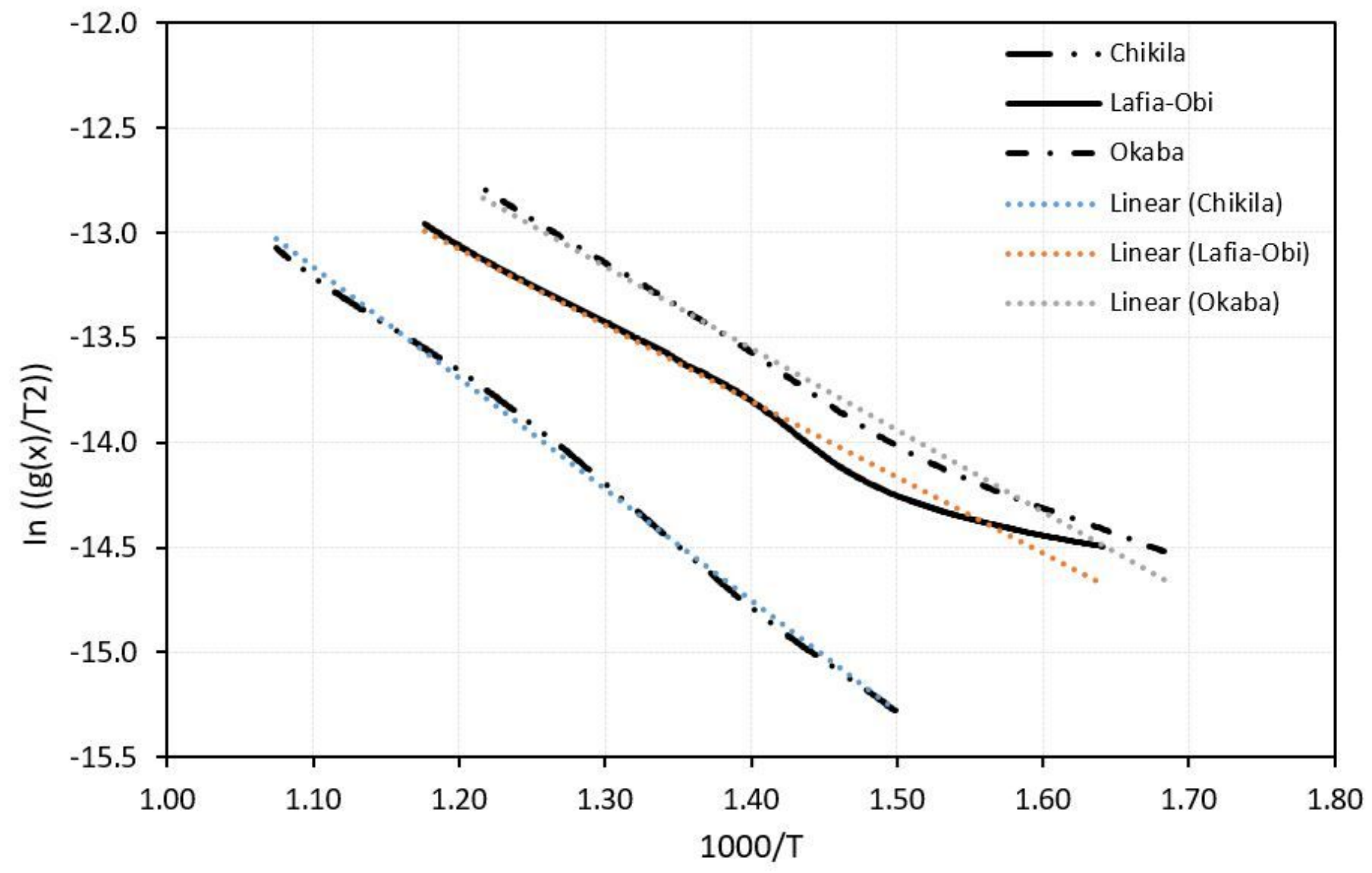

Figure 6

CRM Kinetic Plots for Thermal Degradation of Benue Trough Coals 